UDC 373.2(477) «198/200» (043.3)

DOI: https://doi.org/10.33989/2524-2474.2019.73.180985

\author{
SVITLANA SAYAPINA \\ ORCID: https://orcid.org/0000-0001-5808-7020 \\ (Sloviansk) \\ Place of work: SHEI "Donbas State Pedagogical University" \\ Country: Ukraine \\ Email: pedagogi@i.ua
}

\title{
VARIABILITY OF CONTENT OF SCIENTIFIC INVESTIGATIONS IN PRACTICE OF CREATING AND FUNCTIONING OF DOMESTIC PROGRAMS OF UPBRINGING AND EDUCATING PRESCHOOL CHILDREN (1980 - THE BEGINNING OF THE 21 $^{\text {ST }}$ CENTURY)
}

The program of upbringing at nursery schools has synthesized new achievements of the theory and practice of preschool education, emphasizing the importance of this age period of physical and spiritual development of the child. The aim of the paper is to highlight the scientific and pedagogical investigations in preschool pedagogy, on the basis of which the programs of upbringing and educating preschool children in the period studied have been created and operated. The scientifically and methodically grounded program of upbringing and education of preschool age children is intended to synthesize historical achievements, dissemination of the results of experimental and pedagogical researches into the practice of preschool education, relevant social requirements for it, to meet the peculiarities of cognitive activity of children, to ensure their harmonious development.

Ключові слова: content of scientific investigations; programs; preschool didactics; preschool education; preschool children.

General statement of the problem. In the scientific field, for a long time, a number of contradictions have remained that are objectively present in modern scientific and pedagogical theory and practice, in particular, among: growing interest in the history of native preschool pedagogy and insufficient level of the adequate definition of its essence, scientific principles and role in the historical-pedagogical process; a considerable number of scientific works on the theory and practice of upbringing and educating preschool children, personalistics and a relatively low level of its systematization, problem-thematic, complex analysis; a new strategic course to provide the continuity of education and the lack of scientific investigations on the creation of psychological and pedagogical conditions for its implementation, taking into account the theoretical achievements of preschool pedagogy; the need to develop the innovative technologies for introducing the newest content of upbringing and educating preschool children and the actual state of preparedness of educators-practitioners for such activities; the existing mechanisms of organization, planning of scientific investigations and the need to give them a more systematic, purposeful, coordinated character.

Upbringing and educating preschool children at nursery schools is carried out in accordance with the program - a state document that defines the purpose, tasks and content of educational and upbringing work with children in preschool institutions. The program of upbringing at nursery schools has synthesized new achievements of the theory and practice of preschool education, emphasizing the importance of this age period of physical and spiritual development of the child.

Analysis of researches and publications. General theoretical and practical foundations of preschool pedagogy as a science have deep roots. The definition of its scientific apparatus (object, subject, purpose, tasks, methodological bases, principles, methods of studying the personality of the preschool child) is investigated in the works of the national (N. Heorhyan, V. Zinchenko, N. Lysenko, D. Strunnikova and others) and foreign (T. Babayeva, S. Baranov, L. Bolotina, S. Kozlova, T. Komarova, M. Krulekht, T. Kulikova, O. Solntseva, V. Titov and others) authors. The 
key concepts of preschool pedagogy and preschool education ("preschool upbringing”, "preschool didactics”, “upbringing of children of early age", "physical, mental, moral, labour, aesthetic upbringing", "game”, "toy", "developing environment", "preparation of a child for schooling", "pre-school education", etc.) have been investigated by L. Artemova, H. Byelyenka, A. Bohush, N. Kyrsta, T. Ponimanska, T. Stepanova, O. Usova and other scientists.

The aim of this article. The aim of the paper is to highlight the scientific and pedagogical investigations in preschool pedagogy, on the basis of which the programs of upbringing and educating preschool children in the period studied have been created and operated.

The main material. The problem of developing programs for preschool institutions is one of the most complex theoretical problems of preschool pedagogy. The retrospective analysis of the development of pre-school education shows that the scholars and practitioners are constantly discussing what it should be to ensure uniqueness of preschool education as a special period of childhood maturity and continuity with primary school; to meet the current level of the scientific investigations; to reflect the originality of the educational institution in which it is implemented.

The synonyms of the term "program" are words: plan, project, course, concept. It should be noted that the creator of the program, including the educational one, always focuses on the future, trying to outperform the time and determine the prospects for development. But forecasting becomes successful only if you take into account the present and past experience. The development of the programs the whole period of investigations preceded, there was accumulated significant scientific potential, which required its generalization and comprehension from the standpoint of the possibility of practical implementation of scientific ideas. First of all, such analysis was subjected to the system of vocabulary work developed on the basis of the researches by V. Lohinova and her scientific school. The proposed theoretical foundations of vocabulary work by Ye. Tikheyeva became the subject of the scientific analysis and the basis for improving the content and technology of vocabulary work with preschoolers. As a result of a detailed analysis of the historical heritage by K. Ushinskiy and Ye. Tikheyeva, based on the psychological studies by O. Zaporozhets, O. Leontiev, S. Rubinstein, V. Lohinova developed a slim, logical theory of vocabulary work. This theory allowed radically to change the general idea of the laws of language development of preschool children. The scientific analysis of the theory by Ye. Tikheyeva led V. Lohinova to the idea of the possibility of mastering the socially fixed content of the word at the level of the concept by modern preschoolers. The reason for such opportunities V. Lohinova saw in the phylogenetic growth of intellectual and social abilities of modern preschoolers. In the researches by V. Lohinova and her successors, a new content of the program for the development of the preschool children's dictionary was developed and experimentally tested. The methodological basis of the content, structuring and technology for implementing the program it was developed the theory of system knowledge for preschoolers. Three branches of vocabulary work with preschool children were determined on the basis of the implementation of the principle of the system of knowledge. The possibility of mastering the concepts and conceptual meaning of the word by preschoolers was studied under the guidance of V. Lohinova at the chair of preschool pedagogy in the 80s of the twentieth century in various aspects:

on a different content: while mastering the subject world by pre-school children (the investigations by H. Bavykina, L. Shcherbatykh); while mastering the natural world (the investigations by M. Kondratyev, L. Musatova, T. Markova); while mastering the social world, its central phenomenon - labour (the investigations by L. Misharyna, S. Sudarchykova, N. Krylova, M. Krulekht);

on different language material: when learning and mastering the vocabulary of the Russian and Kazakh languages (the investigations by R. Aralbayeva).

Theoretical positions of the content of the program for the development of coherent speech of children were identified in the studies of H. Leushina. The ideas developed and tested in the researches of H. Leushina became the basis for the development of technology of realization and partial tasks of the development of speech of preschool children. She developed a fundamentally new theory of retelling, considering it as a creative independent activity of the child.

In the process of developing the content of the program the results of the investigations were analysed and taken into account: on the problems of language psychology and communication (F. Sokhin, M. Lisina, L. Halyhuzova, A. Ruzska and others), the methodical aspects of work as to the development of speech of children (O. Ushakova, N. Smolnykova, Ye. Smyrnova, L. Shadryna, N. Havrysh, Ye. Strunina, A. Smaha, Ye. Savushkina, A. Arushanova), the ontolinguistic aspects of language (S. Tseytlin, H. Dobrov, M. Yelisyeyeva, T. Kruhlyakova and others).

In the 90s of the twentieth century, new variational programs were created by the scientists who successfully worked in the integrated "Prohrama vykhovannia ta navchannia v dytiachomu sadku" ("Program 
of Upbringing at Nursery School") (L. Venher, T. Doronova, T. Komarova, L. Paramonova and others). To develop a new one is not so simple, therefore, the programs would be original and, at the same time, reflect the basic provisions of the new Conception of Preschool Education. The ideas of self-worth of pre-school childhood, full-fledged childhood of children, the formation of a basic culture of the personality, value orientations were the bases on which the ideals of the variational programs were being developed and strengthened.

At the initial stage of the developing and improvement of the program of development mathematical representations in children, it was particularly important to use the data of the dissertation papers performed at the chair under the supervision of Doctor of Pedagogical Sciences, Professor H. Leushina. They were the research papers by L. Yermolayeva "Rozumovyi ta matematychnyi rozvytok ditei" ("Mental and Mathematic Development of Children") (1982). The translated sources were used: D. Althaus and E. Dum "Kolir, forma, kilkist" ("Colour, Form, Quantity") (translated from German); Maria Fiedler "Matematyka vzhe v dytiachomu sadu" ("Mathematics Already at Nursery School") (translated from German); R. Green, V. Laksono "Vvedennia u svit chysla" ("Introduction to World of Number") (translated from English); J. Papi, F. Papi "Dity i hrafy" ("Children and Scribes") (translated from German).

During the $80 \mathrm{~s}$ of the $20^{\text {th }}$ century, under the supervision of P. Samorukova, a series of studies was conducted to find the affordable content of knowledge about nature for senior preschool children (I. Khaydurova, Ye. Terentyeva, H. Kondratyeva), as well as to study the possibilities of use the active methods of cognition in the pedagogical process (N. Vyetrova, Ye. Zolotova, N. Kosolapova, A. Matveyeva, L. Manevtsova, N. Sedzh and others). It should be noted that that research work was not directly related to the development of a program for nursery school, as the creation of programs for preschoolers was still strictly regulated by the Ministry of Education.

The scientific and experimental activity of lecturers of the Chair of Preschool Pedagogy RSPU named after O. I. Hertsen in the 70 s and 90 s of the $20^{\text {th }}$ century under the supervision of V. Lohinova and P. Samorukova showed new aspects of structuring knowledge in the program. The system knowledge (as opposed to the traditional systematized ones) was organized in a special hierarchical way, where each subsequent knowledge included the previous one and could not be mastered without it. There was a gradual transition from mastering the specific representations to the generalized representations and elementary concepts by children.

Consequently, the content of the program "Dytynstvo" ("Childhood") as a program of the new generation was based on a large study material of the Chair of Preschool Pedagogy on the development of the idea of holistic personality development, the deployment of system knowledge for preschoolers in various areas of reality.

In modern Ukraine, pre-school institutions have the right to independently choose a program for upbringing children from the range of the variant programs approved by the Ministry of Education and Science of Ukraine, as well as to develop and implement their own. Recently, the scientific groups have created a number of modern programs.

The authors of the "Malyatko" ("Baby") program are the scientists of the Institute of Pedagogy, the Institute of Psychology of the Academy of Pedagogical Sciences of Ukraine, and the pedagogical universities of Ukraine. This program was approved by the Board of the Ministry of Education of Ukraine in 1991 (the second edition in 1999). It defines the tasks and content of upbringing and education of children between two and seven years old; realizes the principles of democratization of the pedagogical process, humanization of the content and methods of upbringing and education children in the preschool institution; focuses on expanding the circle of children's perceptions about the cultural traditions of the Ukrainian people, introducing them to the environment, starting with the closest, most native environment - family, home, village or city; involving them in universal values takes place in the process of forming in children the ideas about parents, genus, genealogy (Поніманська та ін., 1991).

The program "Dytyna" ("Child") was established in 1992 by the staff of Kyiv Interregional Institute for the Improvement of the Teachers named after B. Hrinchenko. It contained an indicative content of upbringing and education of children aged three to seven years old, whose purpose is the formation of the child's personality through the development of his/her mental processes. The program is aimed at humanizing the educational process, harmonizing collective, group and individual forms and methods of work, focusing on individual work with children in all the age groups. It takes into account the conclusions of psychological science about the role of different types of activities and their use in work with children of all ages, the traces of folk pedagogy, folklore, types of national and world art. The principles of integration, systemicity and complexity are also taken into account (Бєлкіна та ін., 2003).

The program "Dytyna v doshkilni roky" ("Child in Preschool Years") was developed in 1991 by Zaporizhzhya scientists and pedagogues-practitioners and addressed to educators and parents. Structurally, 
the material is grouped under the sections "Piznai dytynu" ("Learn Child"), "Zdorova dytyna - zdorove suspilstvo" ("Healthy Child - Healthy Society"), "Tsinnosti doshkilnoho dytynstva ta shliakhy yikh formuvannia" ("Values of Preschool Childhood and Ways of Their Formation"), "Formuvannia kultury piznannia", "Rushiini syly rozvytku doshkilnyka" ("Formation of Culture of Cognition", "Driving Forces of Preschool Child Development"), etc. The "Appendices" contain the approximate tangible material, and the contents - interesting finds by the authors.

The "Ukrainske doshkillia" ("Ukrainian Preschooling”) was created by the team of Lviv Regional Institute for the Improvement of Teachers on the basis of the "Program of Education and Training at Nursery School" (K., 1986) and the experience of the teachers of the 1930s. The program covered the upbringing and education of the children from the fourth to the seventh year of life and focused on working with the children in the following thematic units: mode of life, games, health protection and physical education of children, native land, speech development, formation of initial mathematical representations, aesthetic education and artistic creativity of children, education of the basics of culture of behavior and relationships, labour. The peculiarity of this program was that it was based on the historical and ethnographic material, since the authors considered it as a regional one.

In many domestic preschool institutions in the organization of the upbringing-educational process, the conceptual approaches, individual elements, and even entire educational and training programs, created by the foreign authors, authors' groups, were used in the organization of the educational process ("Veselka" ("Rainbow"), "Rozvitok" ("Development"), "Talanovita Dytyna" ("Talented Child"), "Vitoki" ("Spires"), "Praleska” ("Bluebell”), "Krok za Krokom" ("Step by Step") and others.

The current programs of education and training of children in the educational space of Ukraine are based on the results of the researches in the field of preschool education:

the integrated programs (A. Bohush - "Oberih" ("Charm"), the development program of the children from the prenatal period to three years old; L. Kaluska - "Sonyashnik" ("Sunflower"), the integrated program of the development, education and upbringing of the children of the early age; L. Kaluska - "Sonyashnik" ("Sunflower"), the integrated program of the development, education and upbringing of the preschoolers; V. Ohnevyuk, H. Byelyenka, O. Bohinich, N. Bohdanets-Biloskalenko and others - "Dytyna" ("Child"), the educational program for the children aged from 2 years old to 7 years old; K. Krutiy, A. Bohush, T. Hrytsyshyna, O. Demyanenko and others - "Dytyna v Doshkilni Roki" ("Child in Preschool Years"); A. Bohush, O. Bayyer, L. Batlina, H. Hryhorenko, Z. Doroshenko and others - "Svit Ditinstva" ("World of Childhood"), the integrated educational program for preschool educational institutions; O. Bilan, L. Vozna, O. Maksymenko and others - "Ukrayinske Doshkillya" ("Ukrainian Preschooling"), the program of the development of the preschooler; O. Kononko "Ya u Sviti" ("I Am in the World"), the program of the development of the preschooler; O. Andriyetti, O. Holubovych and others - "Vpevnenyy start" ("Sure Start"), the program of the development of the senior preschoolers; A. Honcharenko, N. Dyatlenko - "Stezhyna" "Pathway"), the program for preschool educational institutions working on Waldorf pedagogy);

the partial programs (I. Kychata, O. Kaplunovska, Yu. Palets, scientifically edited by O. Reypolskaб "Ukrayina - Moya Batkivshchyna" ("Ukraine Is My Motherland"), the program of the national and patriotic upbringing of the preschoolers; T. Pirozhenko, O. Khartman - "Vchymosya Zhyty Razom" ("Learn to Live Together"), the program on the development of the social skills of the efficient interaction of the children aged from 4 years old to 6 - 7 years old; S. Hunko, L. Husak, Z. Leshchenko - "Hrayuchys Vchymosya. Anhliyska Mova" ("Playing and Learning. The English Language"), the program for the senior preschoolers, the methodical recommendations; O. Nyzkovska, I. Kulikova, T. Shkvarina - "Anhliyska Mova dlya Ditey Doshkilnoho Viku" ("English for Preschoolers"), the program and methodical recommendations; R. Borshch, D. Samoylyk - "Radist tvorchosti" ("Joy of Creativity"), the program of artistic and aesthetic development of children of the early and preschool age; O. Berezina, O. Hnirovska, T. Lynnyk - "Hraylyk" ("Playie"), program for the organization of theatrical activity in the preschool educational institution; L. Lokhvytska - "Skarbnytsya Morali" ("Treasury of Morality"), the program for the moral upbringing of the preschoolers; A. Bohush, I. Sidanich, V. Suchok and others - "Dukhovno-Moralne Vykhovannya Ditey Doshkilnoho Viku na Khrystyyanskykh Tsinnostyakh" ("Spiritual and Moral Upbringing of Preschoolers on Christian Values"); L. Lokhvytska - "Pro Sebe Treba Znaty, pro Sebe Treba Dbaty" ("You Need to Know about Yourself, You Need to Take Care of Yourself"), the program on the basics of health and safety of life of children aged from 3 to 6 years old; O. Tymovskyy, I. Repik - "Dytyna u Sviti Dorozhnyoho Rukhu" ("Child in World of Traffic"), the program for forming the bases of safe behaviour of the preschool children during traffic; M. Yefymenko - "Kazkova fizkultura" ("Fairy 
Physical Training"), the program for the physical training of the children of the early and preschool age; M. Yefymenko, Yu. Melnychenko - "Horyzontalnyy Plastychnyy Balet (Plastyk-Shou)" ("Horizontal Plastic Ballet (Plastic-Show)"), the program on physical culture correction work in preschool educational institutions under the authors' aesthetic-improving system; V. Drozdyuk, N. Dyakonova, H. Kovalenko, N. Yakymenko "Shkiryanyy Myach" ("Leather Ball"), the program and methodical recommendations for teaching senior preschoolers playing football; O. Avramenko, V. Drozdyuk, H. Kovalenko, N. Yakymenko - "Nastilnyy Tenis" ("Ping-Pong"), the program and methodical recommendations for teaching senior preschoolers playing table tennis; I. Maslyak, N. Kulyk - "Yunyy Lehkoatlet" ("Young Athlete"), the program for the physical education of the senior preschoolers; A. Shevchuk - "Dytyacha Khoreohrafiya" ("Children's Choreography"); I. Malashevska, S. Demydova - "Veselkova Muzykoterapiya: Ozdorovcho-Osvitnya Robota z Ditmy Starshoho Doshkilnoho Viku" ("Rainbow Music Therapy: Health and Educational Work with Senior preschoolers"); I. Reznichenko - "Smaylyk" ("Smiley"), the program on the formation of the basics of computer literacy of the senior preschoolers; V. Semyzorova, O. Dukhnovska, L. Pashchenko - "Mudri Shakhy" ("Wise Chess"),the program and methodical recommendations for teaching the senior preschoolers chess playing; V. Semyzorova, O. Romanyuk, H. Dulska - "Tsikavi Shashky" ("Interesting Draughts"), the program and methodical recommendations for teaching the senior preschoolers playing draughts; A. Bohush - "Navchannya Ditey Ukrayinskoyi Movy v Doshkilnykh Navchalnykh Zakladakh Natsionalnykh Spilnot" "Teaching Children Ukrainian in Preschool Educational Institutions of National Communities"); T. Buchatska, R. Kochmar "Skarbnytsya Hahauzkoyi Movy, Movy Moyikh Batkiv" ("Treasury of the Gagauz Language, the Language of My Parents"), the educational program for the preschoolers in preschool educational institutions);

the programs for working with children who have special educational needs (V. Zhuk, S. Lytovchenko, N. Maksymenko and others - the program of the development of preschoolers with reduced hearing "Stezhky u Svit" ("Pathways into World"); K. Lutsko - the Program of the Development of Deaf Preschoolers; H. Blech - the program of the development of preschoolers with mental retardation "Rozvitok Movlennya" ("Speech Development"), the methodical recommendations; T. Skrypnyk and others - the integrated program for the development of the preschoolers with autism "Rozkvit" ("Prime"); D. Shulzhenko, K. Ostrovska, Yu. Rybak and others - the Program of the Development of the Preschoolers with the Spectrum of Autistic Disorders; A. Shevtsova - the Program of the Development of the Preschoolers with the Musculoskeletal Disorders; T. Sak - the program of development of preschool children with epy mental retardation from 3 to 7 years old "Vikonechko" ("Windowy"); I. Hudym and others - the Program for the Development of Preschoolers with Severe Visual Impairment; Yu. Ribtsun - the Program-Methodical Complex "Korektsiina Robota z Rozvytku Movlennia Ditei Piatoho Roku Zhyttia iz FonetykoFonematychnym Nedorozvytkom Movlennia" ("Correctional Work on Development of Speech of Children of the Fifth Year of Life with Phonetic and Phonemic Undeveloped Speech"); L. Bartienieva - the Program-Methodical Complex "Korektsiine Navchannia z Rozvytku Movlennia Ditei Starshoho Doshkilnoho Viku iz Fonetyko-Fonematychnym Nedorozvytkom Movlennia" "Correctional Training on the Development of Speech of Senior Preschoolers with Phonetic and Phonemic Undeveloped Speech"); Yu. Ribtsun - the Program-Methodical Complex "Korektsiine Navchannia z Rozvytku Movlennia Ditei Starshoho Doshkilnoho Viku iz Zahalnym Nedorozvytkom Movlennia" ("Correctional Training on the Development of Speech for the Senior Preschoolers with General Underdevelopment of Speech"); A. Vysotska - the Program of the development of the preschoolers with mental retardation "Formuvannia Sotsialnykh Navychok" ("Formation of Social Skills"), the methodical recommendations; A. Minenko, O. Miakushko - "Dovkillia i Rozvytok Movlennia" ("Environment and Speech Development"), the program for the development of the preschoolers with mental retardation, the methodical recommendations; I. Hladchenko - "Fizychne Vykhovannia i Osnovy Zdorovia" ("Physical Upbringing and Health Bases"), the program for the development of the preschoolers with mental retardation, the methodical recommendations; I. Bobrenko "Fizychne Vykhovannia" ("Physical Upbringing"), the program for the development of the preschoolers with mental retardation, the methodical recommendations; O. Vasylevska and others - "Muzychne Vykhovannia" ("Musical Upbringing"), the program for the development of the preschoolers with mental retardation, the methodical recommendations; S. Trykoz - "Obrazotvorcha Diialnist" ("Fine Art Activities"), the program for the development of the preschoolers with mental retardation, the methodical recommendations).

Conclusions. Thus, the scientifically and methodically grounded program of upbringing and education of preschool age children is intended to synthesize historical achievements, dissemination of the results of experimental and pedagogical researches into the practice of preschool education, relevant social requirements for it, to meet the peculiarities of cognitive activity of children, to ensure their harmonious development 


\section{СПИСОК ВИКОРИСТАНОЇ ЛІТЕРАТУРИ}

Дитина. Програма виховання і навчання дітей від 3 до 7 років / Е. В. Бєлкіна та ін. Київ : Богдана, 2003. 327 с. Концепция дошкольного воспитания. Дошкольное воспитание. 1989. № 5. С. 10-23.

Малятко : програма виховання дітей дошкільного віку / Т. І. Поніманська та ін. Київ : МО УРСР, 1991. 198 с. Програма з розвитку українського мовлення дітей для дошкільних закладів з російським мовним режимом : у 2 ч. / під ред.: О. Хорошковської та Н. Кудикіної. Київ, 1992. Ч. II. 96 с.

Саяпіна С. А. Вітчизняна дошкільна педагогіка як наука : становлення та розвиток (1960 p. - початок XXI століття) : монографія. Слов'янськ : Вид-во Б. І. Маторіна, 2016. 410 с.

\section{REFERENCES}

Bielkina, E. V., Proskurav, O. V., Kochyna, L. P., \& Kuzmenko, V. U. (2003). Dytyna. Prohrama vykhovannia i navchannia ditei vid 3 do 7 rokiv [Child. Program of upbringing and education of children from 3 to 7 years old]. Kyiv: Bohdana [in Ukrainian].

Khoroshkovskoi, O. \& Kudykinoi, N. (Eds.). (1992). Prohrama z rozvytku ukrainskoho movlennia ditei dlia doshkilnykh zakladiv z rosiiskym movnym rezhymom [Program for the Development of Ukrainian Broadcasting of Children for Preschools with the Russian Language Regime](Pt. 2). Kyiv [in Ukrainian].

Kontseptsiya doshkol'nogo vospitaniya [The concept of preschool education]. (1989). Doshkol'noe vospitanie [Preschool education], 5. 10-23 [in Russian].

Ponimanska, T. I., Plokhii, Z. P., Kulachkivska, S. Ye., Kondratenko, T. D., Tyshchenko, S. P., Ladyvir, S. O. ... \& Domina, I. S. (1991). Maliatko : prohrama vykhovannia ditei doshkilnoho viku [Malyatko: program of upbringing children of preschool age]. Kyiv: MO URSR [in Ukrainian].

Saiapina, S. A. (2016). Vitchyzniana doshkilna pedahohika yak nauka : stanovlennia ta rozvytok (1960 r - pochatok XXI stolittia) [Domestic preschool pedagogy as a science: formation and development (1960 - the beginning of the XXI century)]. Slov'iansk: Vyd-vo B. I. Matorina Kyiv [in Ukrainian].

\section{СВІТЛАНА САЯПІНА}

\section{ВАРІАТИВНІСТЬ ЗМІСТУ НАУКОВИХ ДОСЛІДЖЕНЬ У ПРАКТИЦІ СТВОРЕННЯ Й ФУНКЦІОНУВАННЯ ВІТ- ЧИЗНЯНИХ ПРОГРАМ ВИХОВАННЯ ТА НАВЧАННЯ ДІТЕЙ ДОШКІЛЬНОГО ВІКУ (1980 РР - ПОЧАТОК ХХІ СТОЛІТТЯ)}

Анотація. Виховання та навчання дітей дошкільного віку в дитячому садку здійснюється відповідно до програми - державного документа, який визначає мету, завдання і зміст навчально-виховної роботи 3 дітьми в дошкільному закладі. Програма виховання в дитячому садку синтезувала в собі нові здобутки теорії та практики дошкільного виховання, підкреслюючи значення цього вікового періоду фізичного й духовного розвитку дитини.

Мета статті полягає у висвітленні науково-педагогічних досліджень із дошкільної педагогіки, на засадах яких створювалися та функціонували програми виховання та навчання дітей дошкільного віку в досліджуваний період. Проблема розробки програм для дошкільних установ є однією з найбільш складних теоретичних проблем дошкільної педагогіки. Ретроспективний аналіз розвитку дошкільної освіти показує, що вчені та практики постійно обговорюють питання про те, якою вона повинна бути, щоб забезпечувати унікальність дошкільної освіти як особливого періоду дитячого дорослішання та спадкоємність з початковою школою; відповідати сучасному рівню наукових досліджень; відображати своєрідність освітнього закладу, у якому реалізується.

Синонімами терміна „програма” є слова: план, проект, курс, концепція. Визначено, що творець програми, зокрема й освітньої, завжди орієнтується на майбутнє, намагаючись випередити час і визначити перспективи розвитку. Але прогнозування стає успішним лише за врахування умов сьогодення та досвіду минулого. Розробці програм передувала ціла епоха досліджень, було накопичено значний науковий потенціал, який потребує свого узагальнення й осмислення з позицій можливості практичної реалізації наукових ідей.

У сучасній Україні дошкільні заклади мають право самостійно обирати програму виховання дітей із комплексу варіантних програм, затверджених Міністерством освіти і науки України, а також розробляти й упроваджувати власні. Останнім часом наукові колективи створили низку сучасних програм.

Науково-методично обгрунтована програма виховання та навчання дітей дошкільного віку покликана синтезувати історичні надбання, поширення результатів експериментально-педагогічних досліджень у практику дошкільної освіти, актуальні суспільні вимоги до неї, відповідати особливостям пізнавальної діяльності дітей, забезпечувати їхній гармонійний розвиток.

Одержано 11.02.2019p. 